TEME, г. XLV, бр. 1, јануар - март 2021, стр. 315-330

\begin{tabular}{lr}
\hline Прегледни рад & https://doi.org/10.22190/TEME200129017T \\
Примљено: 29. 1.2020. & UDK 338.483(497.113)
\end{tabular}

Ревидирана верзија: 26. 7. 2020.

Одобрено за штампу: 26. 2. 2021.

\title{
THE FUNCTION OF PROTECTED NATURAL AREAS OF THE VOJVODINA PROVINCE IN SUSTAINABLE TOURISM DEVELOPMENT
}

\author{
Igor Trišić
}

The University of Kragujevac, Faculty of Hotel Management and Tourism,

Vrnjačka Banja, Serbia

\begin{abstract}
To determine the state of sustainable tourism development in the protected natural areas of AP Vojvodina, it is important to analyze and correlate certain indicators of sustainable tourism. It is also important to analyze the opinion of visitors according to the selected protected natural areas, from the perspective of experiences and potential suggestions for specific interventions, to improve the state of natural values and improve the area protection. As a final result, it can provide significant benefits for all participants of sustainable tourism development. This paper analyzed and presented the results of visitor responses regarding 5 selected protected natural areas on the territory of AP Vojvodina. These areas represent a significant sample for analysis and the results of the research can influence the overall assessment of the sustainable tourism development of the Province. Using the correlation method of obtained average values of estimated sustainability indicators, the relation of these indicators to sustainable tourism was defined. The results obtained can influence the constitution of proposals for the improvement of the natural values of these areas through the proper implementation of nature protection. By enhancing these natural values, benefits are provided to all participants in sustainable tourism development.
\end{abstract}

Key words: $\quad$ sustainable tourism development, protected natural areas, nature-based tourism, AP Vojvodina, Pearson Correlation.

\section{ФУНКЦИЈА ЗАШТИЋЕНИХ ПРИРОДНИХ ПОДРУЧЈА ВОЈВОДИНЕ У ОДРЖИВОМ ТУРИСТИЧКОМ РАЗВОЈУ}

\section{Апстракт}

За утврђивање стања одрживог туристичког развоја у заштићеним природним просторима АП Војводине, значајно је извршити анализу и корелацију од-

\footnotetext{
* Аутор за кореспонденцију: Игор Тришић, Факултет за хотелијерство и туризам, Војвођанска 5а, 36210 Врњачка Бања, Србија, trisici@hotmail.com
} 
ређених индикатора одрживог туризма. Исто тако, важно је анализирати ставове посетилаца одабраних заштићених природних простора, са аспекта искустава и могућих сугестија ка одређеним интервенцијама, у циљу побољшања стања природних елемената и унапређења заштите простора, што као коначни резултат може дати значајне погодности за све субјекате одрживог туристичког развоја. У раду су анализирани и приказани резултати одговора посетилаца пет одабраних заштићених природних простора на територији АП Војводине. Ови простори представљају значајан узорак за анализу, а резултати могу послужити у укупној оцени одрживог туристичког развоја Покрајине. Методом корелације добијених просечних вредности оцењених индикатора одрживости дефинисан је однос ових индикатора према одрживом туристичком развоју. Добијени резултати могу утицати на конституисање предлога унапређења природних вредности ових простора кроз правилну примену заштите. Повећањем ових вредности обезбеђују се погодности свим субјектима у одрживом туристичком развоју.

Кључне речи: одрживи туристички развој, заштићени природни простори, туризам заснован на природи, АП Војводина, Пирсонова корелација.

\section{INTRODUCTION}

Protected areas of the Autonomous Province of Vojvodina are certain areas with very attractive character. Many activities are limited in those areas since they can change the area and influence the natural resources and the entirety of the wildlife. Protected natural areas of Vojvodina have certain characteristics that they are protected for. Most often these indicators are as follows: rare wildlife species and their spacial vulnerability, unique areas such as wetlands, sandy and alluvial terrains, unspoiled nature and other factors. These areas often unite significant economic, cultural, scientific and ecological values of its territory (Milićević et al., 2020), and that is the reason for their preservation (Bennett el al., 2018; Stojanović et al., 2018). The concept of such area protection should allow the use of resources but only in a sustainable and renewable way (Wardle et al., 2018; Cvijanović et al., 2020). It can additionally increase the tourist value of such destinations. State, local community, conservationists, researchers and tourists using the area have interest regarding the protection and preservation of these areas. The task of this paper is the analysis and comparison of certain indicators of sustainable tourism, within 5 selected protected natural areas of the Autonomous Province of Vojvodina. After the analysis of the obtained average values from the respondents' answers, it is possible to derive the guidelines towards the improvement of sustainable tourism development. These suggestions can include different anthropogenic activities and forms of tourism. It is, also, the objective of this paper.

Protected natural areas of Vojvodina with properly planned tourism development, which includes all sustainability factors, can represent significant tourism potential (Trišić, 2020). Possible forms of tourism in these des- 
tinations are ecotourism, trips, science tourism, nature-based tourism, sports tourism, evening, wine tourism, bird and animals watching, cycling, tracking, etc. All mentioned forms of tourism can contribute to the improvement of the protection of these areas (Bello, Carr \& Lovelock, 2016; Buclet \& Lazarević, 2017). The field of the research consisted of one national park and 4 special nature reserves, significant in terms of the offer of nature-based tourism of Vojvodina. The paper used the written questionnaire method. The respondents were asked 26 questions as part of the written questionnaire, referring to the attitudes towards the specific indicators of sustainable tourism within the visited area. Research data have been collected through a questionnaire, processed and displayed by the One-Sample Test and Pearson Correlation Analysis, which identified average values and obvious differences in displayed values of sustainable tourism development factors in selected protected areas. As the final result of the protection impact on quality and type of destination, environmental, economic and socio-cultural benefits are allocated to all participants in this unique system.

\section{LITERATURE REVIEW}

In this chapter, the author reviewed relevant current research and made a connection with their research. Research by prominent author makes a significant starting point for scientific work in this paper. To understand the correlation between the protected areas and sustainable tourism development in the best possible way, it is necessary to analyze the historical data regarding the chronology of establishment of different statuses and protection regime of certain areas (Newsome, Moore \& Dowling, 2013; Geneletti, Scolozzi, \& Esmail, 2018). It enables the role of protected areas in the sustainable development of the AP of Vojvodina is adequately perceived (Štetić \& Trišić, 2018). It is also significant to analyse the data of certain authors, who researched the relationship between sustainable tourism development and protected natural areas.

In his study, Stojanović defined and described the first forms of protection recorded in 1273 in London when the oldest protection measure was adopted, and it referred to the limitation of smoke and ash effects. Nature reserve - Forest of Fontainebleau, near Paris, was the first one with the protection status acquired in 1848, and then Yosemite Valley, in the USA, acquired it in 1864. Forest of Fontainebleau protection was the action carried out by the naturalists, artists and nature lovers. The objective was to maintain the balance in the exploitation of natural resources, because of the increasing need of the urban population for spending time outdoors (Stojanović, 2011). Soon after, inspired by these examples, all around the world protection regimes started to be established in different areas and on different levels. Protection statuses were acquired by the first national parks, and the first national park Yellowstone in the USA obtained the status on $1^{\text {st }}$ March 1872, 
so therefore it was the first national park in the world. In Europe, Abisko National Park in Sweden was established in 1909, and then Engadin in Switzerland in 1914 (Williams \& Lew, 2015; Trišić, Štetić \& Krstić, 2018). In the area of Vojvodina, Obedska Pond acquired the protection status in 1874 , and it was the first form of protected area in the Republic of Serbia (Nikolić, 2006). Fruška Gora, the first national park, was established on $23^{\text {rd }}$ December 1960. According to Lazić (2008), protection of natural beauty, historical monuments, wildlife and land characteristics were emphasized as the reasons for the establishment of the national park (Lazić et al., 2008). Protected natural areas have significant natural resources such as soil (Maksin et al., 2018), wetland ecosystems, diverse terrains and special representatives of flora and fauna (Trišić et al., 2020). Different proposals of measures for the improvement of these values can be constituted by the analysis and correlation of the sustainability indicators (Brandt et al., 2013; Saarinen, Rogerson \& Hall, 2017). The author's Carr, Ruhanen and Whitford consider as significant that realization of ecological, economic and sociocultural values in tourism destinations, is the basic principle of sustainable tourism development (Carr, Ruhanen \& Whitford, 2016). The results of their research contributed to the research in this article.

Tourism is the direct moderator of areas (Štetić, Trišić \& Nedelcu, 2019) by different influences which are the result of direct use of areas (Hall, 2010). All significant activities of tourism in the specific protected area and development risks, resulting from it, influencing the most significant elements of the environment while creating destinations, can be seen in the following Table 1.

The results of cited research contributed to the research in this article. The author researched the influence of the importance of the selected protected natural areas of Vojvodina on sustainable development.

\section{METHOD}

In AP of Vojvodina there are 21 internationally important areas for birds (Important Bird Areas - IBA), a total area of 354,786ha, which together occupy $16.5 \%$ of Vojvodina's territory. Among the most significant ones are the following: Gornje Podunavlje, Karadjordjevo, Subotica lakes and sandy terrain, Jegrička, Danube loess bluffs, etc (Trišić, Štetić \& Krstić, 2018). Within the IPA (Important Plant Areas) on the territory of Vojvodina, 27 areas with the total area of $328,208 \mathrm{ha}$ or $15.3 \%$ have been singled out. Significant IPA areas in Vojvodina are Fruška Gora Mountain, The moor of Kovilj, Obedska Pond, Imperial Pond, Salt Marshes "Slano Kopovo", Upper Danube Valley, Deliblato Sands, Zasavica Moor, Meadows of Great Bustard, Vršac Mountains, Subotica sandy terrain, Palić Lake, Ludaš Lake, etc. (Panjković, 2016). In AP of Vojvodina there are 4 Prime Butterfly Areas (PBA), a total area of 91,107 ha which makes $4.2 \%$ of its territory (Stojnić et al., 2015). 
Table 1. The tourism relation to certain factors and elements of the destination

\begin{tabular}{|c|c|}
\hline Element & Examples of risk from tourism activities \\
\hline Ecosystems & $\begin{array}{l}\text { The construction of accommodation, visitor centers, infrastructure, } \\
\text { and other services has a direct impact on the environment, from } \\
\text { vegetation removal, animal disturbance elimination of habitats, } \\
\text { impacts on drainage etc; } \\
\text { - Wildlife habitat may be significantly changed (travel routes, hunting } \\
\text { areas, breeding areas, etc.) by all kinds of tourist development and } \\
\text { use. }\end{array}$ \\
\hline Soils & $\begin{array}{l}\text { - Soil compaction can occur in certain well-used areas; } \\
\text { - Soil removal and erosion also occurs and may continue after the } \\
\text { disturbance is gone. }\end{array}$ \\
\hline Vegetation & $\begin{array}{l}\text { - Concentrated use around facilities has a negative effect on } \\
\text { vegetation; } \\
\text { - Transportation may have direct negative impacts on the environment } \\
\text { (e.g. vegetation removal, weed transmission, animal disturbance); } \\
\text { - Fire frequency may change due to tourists and park tourism } \\
\text { management. }\end{array}$ \\
\hline Water & $\begin{array}{l}\text { - Increased demands for freshwater; } \\
\text { - Disposal of sewage or litter in rivers, lakes or oceans; } \\
\text { - Release of oil and fuel from ships and smaller craft; } \\
\text { - Propeller-driven watercraft may affect certain aquatic plants and } \\
\text { species. }\end{array}$ \\
\hline Air & $\begin{array}{l}\text { Motorized transportation may cause pollution from emissions (from } \\
\text { the plane, train, ship or automobile). }\end{array}$ \\
\hline Wildlife & $\begin{array}{l}\text { - Hunting and fishing may change population dynamics; } \\
\text { - Hunters and fishers may demand the introduction of foreign species, } \\
\text { and increased populations of target animals; } \\
\text { - Impacts occur on insects and small invertebrates, from effects of } \\
\text { transportation, introduced species, etc; } \\
\text { - Disturbance by visitors can occur for all species, including those that } \\
\text { are not attracting visitors; } \\
\text { - Disturbance can be of several kinds: noise, visual or harassing } \\
\text { behavior; } \\
\text { - The impact can last beyond the time of initial contact (e.g. before } \\
\text { heart-rate returns to normal, or before birds alight, or mammals } \\
\text { resume breeding or eating); } \\
\text { - Marine mammals may be hurt or killed by boat impacts or propeller } \\
\text { cuts; } \\
\text { - Habituation to humans can cause changed wildlife behavior, such as } \\
\text { approaching people for food. }\end{array}$ \\
\hline
\end{tabular}


5,989ha has been placed under the first degree of protection $(4.47 \%$ of the total number of protected areas), or $0.28 \%$ of the territory of APV. The second degree of protection has been assigned to 50,964.37ha of the protected areas (38\%), or $2.4 \%$ of the territory of the AP. The third degree of protection includes $84,091.28$ ha of the protected areas of the APV (57.53\%) or $3.88 \%$ of APV's territory.

The protection covers: 1 national park, 3 regions of exceptional characteristics, 16 specialized nature reserves, 10 nature parks, 1 scientific research reserve, 53 natural monuments, 3 memorial natural monuments, as well as natural assets of other categories (Trišić, Štetić \& Krstić, 2018). Several natural areas have international status or are nominated to acquire it (Puzović et al., 2015). All the data above are shown in Table 2.

Table 2. Overview of the number of protected areas on the territory of APV

\begin{tabular}{|c|c|c|}
\hline Type of protected & ha & $\begin{array}{c}\text { Autonomous Province of } \\
\text { Vojvodina \% } \\
\text { (Total Area) }\end{array}$ \\
\hline Ramsar sites & 57,255 & 2.65 \\
\hline IBA & 354,786 & 16.41 \\
\hline IPA & 328,208 & 15.18 \\
\hline PBA & 91,107 & 4.22 \\
\hline$\Sigma_{1}$ & $831,356.00$ & 38.46 \\
\hline Under the first degree of protection & 5,989 & 0.28 \\
\hline Under the second degree of protection & $50,964.37$ & 3.58 \\
\hline Under the third degree of protection & $84,091.28$ & 4.12 \\
\hline $\begin{array}{c}\Sigma_{1} \in \Sigma_{2} \\
(135 \text { sites }) \\
\end{array}$ & $141,044.65$ & 7.98 \\
\hline
\end{tabular}

Source: Author

By analyzing the data in Table 1, it can be noticed that the areas under the international management regimes (Ramsar Areas, IBA, IPA, and PBA) are 690,311ha larger compared to the established regimes of I, II, and III degrees of protection, regulated by the Law on Protection of Nature of the Republic of Serbia (Zakon o zaštiti prirode ("Službeni Glasnik RS“, br. 36/2009, 88/2010, 91/2010 - ispr. i 14/2016)). It is also noted that there is the case of territory overlap, that is, one territory or its part can be submitted to various types of protection. There is significant data about 135 natural sites, on the total area of 141,044.65ha, being submitted to the protection. This makes $7.98 \%$ of the total area of the Vojvodina Province $(2,161,400 \mathrm{ha})$. In the group of nationally and internationally significant species on the area of Vojvodina 455 taxa were recorded, in the tier of species (353) and subspecies (102). Based on Preliminary List of Species for the threat status of the Red List of Flora of Serbia - The Red Data Book of Flora of Serbia 1, according to the IUCN 
criteria from 2001, that is, threat status revision of some taxa of Vojvodina, it is possible to select 270 species (Stojnić et al., 2015).

Analysis and correlation of the selected indicators of sustainable tourism have been carried out, in this paper, to determine the state of sustainable tourism development in the AP of Vojvodina. Also, the attitudes of the users of these areas have been analyzed in terms of the experience and potential suggestions towards the specific interventions for the improvement of the conditions of natural elements, state and the results of environmental protection, which can provide the increase of benefits for all entities of the sustainable tourism development as the final result (Stojanović, 2011; Holden, 2016). When the roles of every factor of sustainable tourism development are defined and determined in the selected protected areas of AP of Vojvodina, certain proposals for the constitution of systemic measures and specific objectives of protection can be given (Fennell, 2015; Trišić, 2019). Comparative analysis of these selected indicators of sustainability and their state can be used for defining the role of protected natural areas with regard to the sustainable tourism development of AP of Vojvodina. Based on the above mentioned, the research has been carried out by the author, in order to determine the significance of the specific factors within the selected protected areas. These selected protected areas can represent a significant sample for the analysis of the total state of the sustainable tourism development of AP of Vojvodina. In 2018, the questionnaire was distributed by the author among 250 users of protected natural areas during their visits or after the finished journey in the 5 selected protected natural areas of AP of Vojvodina (Figure 1). For the research in this paper, data were obtained by a written questionnaire. The questionnaire contained 26 questions in the form of statements and the respondents entered their answer to each of the statements. The field of research consisted of one national park and 4 special nature reserves, significant in terms of the offer of nature-based tourism of Vojvodina. The respondents were asked 26 questions as part of the written questionnaire, referring to the attitudes towards the specific indicators of sustainable tourism within the visited area. Respondents gave answers only regarding the state of the indicators of sustainability of the given protected areas they visited, meaning they did not visit all the suggested protected areas. With regard to the elements for examination and comparative analysis of sustainable development and protection, indicators which are an integral part of destinations, such as endangered representatives of flora and fauna, reasons for and needs of protection, degree of development and endangerment, anthropogenic influences grouped by the effect levels, methods of protection improvement if it is stable, the role of the local community and sustainable results of proper management have been taken into consideration. Respondents answered the question regarding tourist activities, and answers were ranked on a 
Likert scale (Joshi et al., 2015). This ranking of answers is identical to the answers rated in the author's questionnaire, i.e. with the answers ranked by relevance on the following scale: 1 - I absolutely disagree, 2 - I disagree, 3 - I'm not sure, 4 - It's mostly true, 5 - I completely agree. By the method of data descriptive analysis using SPSS software (Statistical Package for the Social Sciences), the obtained results were examined and tabulated. Obtained differences in certain responses were examined by One-Sample Test analysis. Correlation of average indicator values was examined by the method of Analysis of The Pearson Correlation. By the method of data descriptive analysis using SPSS software, the results obtained were examined and tabulated. Obtained differences in certain responses were examined by One-Sample Test analysis. The existence of variables was examined and shown by the Pearson Correlation analysis indicators method to determine if the obtained differences model is relevant to the result analysis.

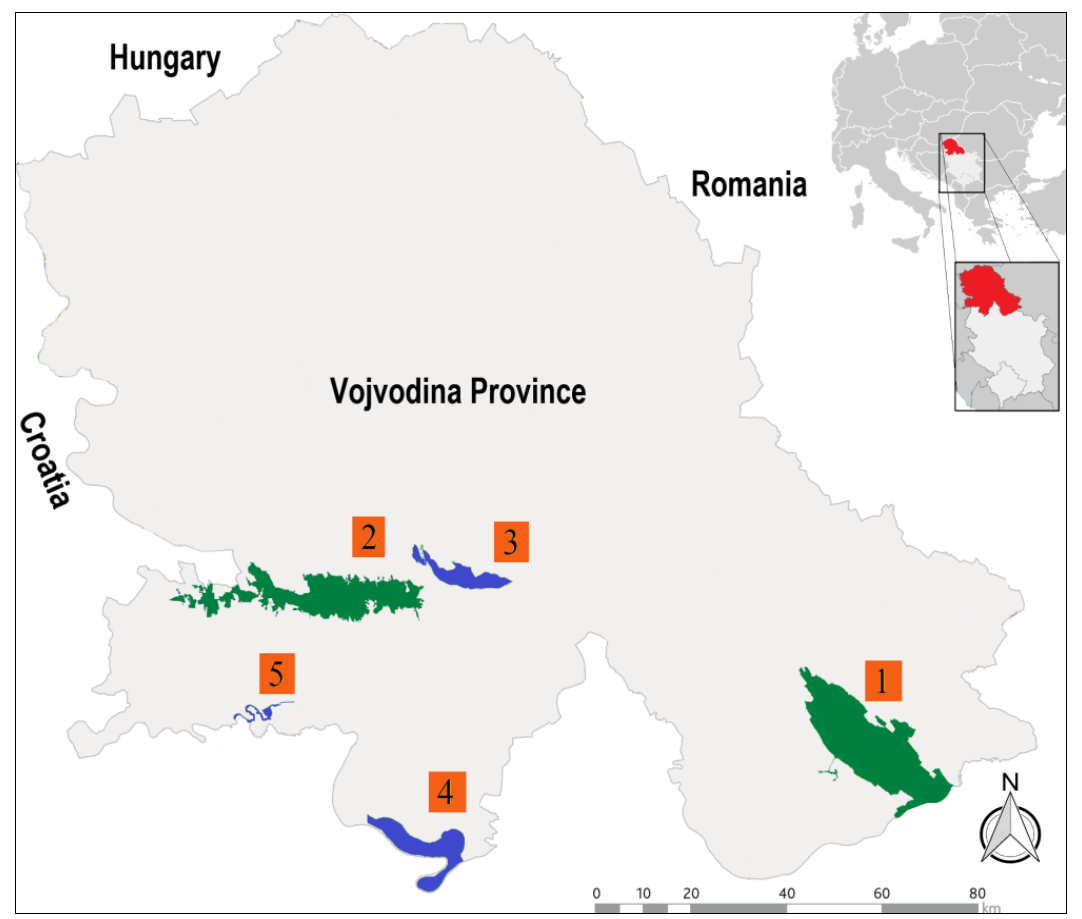

Figure 1. Map of the study area

Legend: Special Nature Reserve "Deliblatska Peščara" (1); National Park "Fruška Gora" (2); Special Nature Reserve "Koviljsko-Petrovaradinski Rit" (3); Special Nature Reserve "Obedska Bara" (4); Special Nature Reserve "Zasavica" (5). Source: author digitalized 


\section{RESULTS AND DISCUSSION}

Respondents traveled, at least once, to the selected protected areas being the subject of research and used the specific services within them. Respondents are from the following cities: Beograd, Zagreb, Beč, Banja Luka, Novi Sad, Pančevo and Niš. Each respondent stated which protected areas he/she had visited up to the moment of the survey. The structure of the respondents is shown in Table 3.

Table 3. Respondents' profile

\begin{tabular}{|c|c|c|c|}
\hline Gender & Frequency & \multicolumn{2}{|c|}{ Percent } \\
\hline Male & 112 & \multicolumn{2}{|c|}{44.8} \\
\hline Female & 138 & \multicolumn{2}{|c|}{55.2} \\
\hline Total & 250 & \multicolumn{2}{|c|}{100.0} \\
\hline Education level & Frequency & \multicolumn{2}{|c|}{ Percent } \\
\hline Primary education & 20 & \multicolumn{2}{|c|}{8} \\
\hline Secondary education & 84 & \multicolumn{2}{|c|}{33.6} \\
\hline Higher education & 105 & \multicolumn{2}{|c|}{42} \\
\hline High education & 41 & \multicolumn{2}{|c|}{16.4} \\
\hline Total & 250 & \multicolumn{2}{|c|}{100.0} \\
\hline \multirow[t]{4}{*}{ Age structure } & $\mathrm{N}$ & Min & \multirow{2}{*}{$\begin{array}{c}\operatorname{Max} \\
72\end{array}$} \\
\hline & 250 & 19 & \\
\hline & mean & \multirow{2}{*}{\multicolumn{2}{|c|}{$\begin{array}{l}\text { std. dev. } \\
15.851\end{array}$}} \\
\hline & 32.17 & & \\
\hline \multirow[t]{2}{*}{ Visited protected area } & Respon & & \multirow{2}{*}{$\begin{array}{l}\text { Percent } \\
\text { of case }\end{array}$} \\
\hline & Frequency & $\overline{\text { Percent }}$ & \\
\hline National Park „Fruška Gora“ & 220 & 33.49 & 88.0 \\
\hline Special Nature Reserve „Zasavica“ & 198 & 30.13 & 79.2 \\
\hline Special Nature Reserve „Deliblatska Peščara“ & 157 & 23.90 & 62.8 \\
\hline Special Nature Reserve „Obedska Bara“ & 44 & 6.70 & 17.6 \\
\hline $\begin{array}{l}\text { Special Nature Reserve „Koviljsko- } \\
\text { Petrovaradinski Rit“" }\end{array}$ & 38 & 5.78 & 15.2 \\
\hline Total & 657 & 100.00 & $\overline{274.8}$ \\
\hline
\end{tabular}

Source: Author

For the analysis of the current state, the selected protected areas have been taken into consideration, which can represent a significant sample for determination of stability of relevant indicators of sustainable tourism (Eagles, 2014) and through which tourist destination can be successfully managed (Butzmann \& Job, 2017). Obtained results, after the analysis of the responses, are shown in the form of means, by the percentage of accuracy and presence. The display of average positive and negative values and conditions, obtained after the analysis of respondents' answers, are shown in Table 4. 
Table 4. Analysis of indicators of sustainable tourism for selected protected natural areas

\begin{tabular}{|c|c|c|c|c|c|}
\hline \multirow{2}{*}{ Indicators } & DP & FG & KPR & $\mathrm{OB}$ & ZA \\
\hline & \multicolumn{5}{|c|}{ Average } \\
\hline 1. Favorable location & 3.82 & 4.02 & 3.13 & 3.17 & 3.11 \\
\hline 2. There are transport infrastructures & 4.47 & 4.69 & 2.28 & 4.32 & 3.42 \\
\hline 3. Adequate area protection status & 3.54 & 3.17 & 3.67 & 4.47 & 4.06 \\
\hline 4. International protection status & 4.03 & 3.11 & 3.74 & 4.31 & 4.05 \\
\hline $\begin{array}{l}\text { 5. Sufficient number of supporting } \\
\text { facilities constructed }\end{array}$ & 3.21 & 3.42 & 2.19 & 4.12 & 3.17 \\
\hline 6. There are accommodation facilities & 4.01 & 3.03 & 2.11 & 2.24 & 2.11 \\
\hline $\begin{array}{l}\text { 7. The importance of area protection for } \\
\text { the viability of species }\end{array}$ & 4.44 & 3.02 & 4.11 & 4.27 & 4.82 \\
\hline $\begin{array}{l}\text { 8. The role of the local community is } \\
\text { significant }\end{array}$ & 3.74 & 4.01 & 4.19 & 4.74 & 4.89 \\
\hline 9. Possible ecotourism & 3.51 & 3.81 & 3.27 & 3.44 & 2.54 \\
\hline 10. There are events & 2.28 & 3.14 & 2.47 & 2.02 & 1.74 \\
\hline 11. An adequate visitor center was built & 4.44 & 4.11 & 2.44 & 4.32 & 4.84 \\
\hline 12. Hiking and educational trails are marked & 4.62 & 4.33 & 2.13 & 4.17 & 3.37 \\
\hline 13. There are eco-trails & 4.64 & 3.68 & 1.21 & 1.54 & 2.21 \\
\hline 14. The carrying capacity is applied & 3.17 & 2.11 & 1.14 & 2.59 & 3.69 \\
\hline 15. Rare species are present & 4.79 & 2.41 & 4.21 & 4.42 & 4.71 \\
\hline 16. There are trips & 4.52 & 4.14 & 4.35 & 4.22 & 4.40 \\
\hline $\begin{array}{l}\text { 17. The possibility of developing science } \\
\text { tourism }\end{array}$ & 4.81 & 4.80 & 4.62 & 4.82 & 4.91 \\
\hline $\begin{array}{l}\text { 18. The possibility of animals and bird } \\
\text { watching }\end{array}$ & 4.62 & 4.48 & 4.52 & 4.61 & 4.68 \\
\hline 19. Waste pollution eliminated & 4.54 & 3.11 & 2.52 & 3.81 & 3.09 \\
\hline 20. There are hydrographic potentials & 3.16 & 4.32 & 5.00 & 5.00 & 5.00 \\
\hline 21 . There are ethno villages & 2.41 & 2.47 & 4.54 & 3.36 & 4.89 \\
\hline $\begin{array}{l}\text { 22. There are potential environmental } \\
\text { pollutants nearby }\end{array}$ & 4.54 & 2.14 & 4.37 & 4.50 & 4.71 \\
\hline $\begin{array}{l}\text { 23. Using natural resources for tourism } \\
\text { purposes }\end{array}$ & 4.16 & 4.12 & 4.57 & 4.11 & 4.54 \\
\hline 24. Possible negative socio-cultural influences & 1.29 & 2.12 & 2.37 & 2.25 & 2.11 \\
\hline $\begin{array}{l}\text { 25. There are endangered species according } \\
\text { to IUCN }\end{array}$ & 4.25 & 3.92 & 4.62 & 4.81 & 4.53 \\
\hline 26. There are agricultural terrain nearby & 5.00 & 4.62 & 5.00 & 4.47 & 4.51 \\
\hline
\end{tabular}

Through the analysis of Table 4, it can be observed that the indicators of sustainable tourism with highest average values marked in the protected areas are as follows: the significance of protection for species sustainability, the existence of hydrographic potential, the possibility of science tourism de- 
velopment, animals and bird watching, the existence of endangered wildlife, as well as indicators referring to the infrastructure within the area. The possible threats for the protected areas, specified by the respondents, are as follows: the vicinity of agricultural terrain, the vulnerability of species with IUNC status, the use of natural resources for tourism or other purposes and the vicinity of potential environmental pollutants. The given responses referring to indicators of sustainable tourism, are statistically shown in Table 5.

Table 5. Statistics of sustainable tourism indicators

\begin{tabular}{|c|c|c|c|c|c|c|}
\hline & & DP & FG & KPR & OB & $\mathrm{ZA}$ \\
\hline \multirow{2}{*}{$\mathrm{N}$} & Valid & 26 & 26 & 26 & 26 & 26 \\
\hline & Missing & 0 & 0 & 0 & 0 & 0 \\
\hline \multicolumn{2}{|c|}{ Mean } & 3.96 & 3.46 & 3.38 & 3.73 & 3.92 \\
\hline \multicolumn{2}{|c|}{ Std. Deviation } & 1.076 & .948 & 1.359 & .962 & 1.164 \\
\hline \multicolumn{2}{|c|}{ Variance } & 1.158 & .898 & 1.846 & .925 & 1.354 \\
\hline \multicolumn{2}{|c|}{ Minimum } & 1 & 2 & 1 & 2 & 2 \\
\hline \multicolumn{2}{|c|}{ Maximum } & 5 & 5 & 5 & 5 & 5 \\
\hline \multicolumn{2}{|c|}{ Sum } & 103 & 90 & 88 & 97 & 102 \\
\hline
\end{tabular}

Through the analysis of data in Table 5, it can be observed that Special Nature Reserve "Deliblatska Peščara" and Special Nature Reserve "Zasavica", have the highest average values. During the analysis of shown indicators, it is important to determine if there are significant differences in the answers given by the respondents. This can be determined through OneSimple Test. The analysis is shown in Table 6.

Table 6. One-Sample Test

\begin{tabular}{lcccccc}
\hline & & \multicolumn{2}{c}{ Test Value $=0$} \\
& & & Mean & \multicolumn{2}{c}{$\begin{array}{c}\text { 95\% Confidence } \\
\text { Interval of the } \\
\text { Difference }\end{array}$} \\
\cline { 3 - 7 } & & df & Sig. (2-tailed) & $\begin{array}{c}\text { Lower } \\
\text { Difference }\end{array}$ & Upper \\
\hline DP & 18,768 & 25 & .000 & 3.962 & 3.53 & 4.40 \\
FG & 18,621 & 25 & .000 & 3.462 & 3.08 & 3.84 \\
KPR & 12,702 & 25 & .000 & 3.385 & 2.84 & 3.93 \\
OB & 19,784 & 25 & .000 & 3.731 & 3.34 & 4.12 \\
ZA & 17,192 & 25 & .000 & 3.923 & 3.45 & 4.39 \\
\hline \multicolumn{3}{c}{ Source: Author }
\end{tabular}

Through the analysis of data in Table 6 , it is concluded that there are significant differences in the respondents' answers. Those differences are observed through the analysis of average values of indicators in the protected areas. It can be examined if the obtained values are in correlation with Pearson Correlation Analysis (Table 7). 
Table 7. Indicators correlation

\begin{tabular}{|c|c|c|c|c|c|c|}
\hline & & DP & FG & KPR & OB & $\mathrm{ZA}$ \\
\hline \multirow[t]{3}{*}{$\overline{\mathrm{DP}}$} & Pearson Correlation & 1 & $.449^{*}$ & .229 & $.453^{*}$ & .285 \\
\hline & Sig. (2-tailed) & & .021 & .260 & .020 & .158 \\
\hline & $\mathrm{N}$ & 26 & 26 & 26 & 26 & 26 \\
\hline \multirow[t]{3}{*}{$\overline{\mathrm{FG}}$} & Pearson Correlation & $.449^{*}$ & 1 & .198 & $.405^{*}$ & .106 \\
\hline & Sig. (2-tailed) & .021 & & .332 & .040 & .606 \\
\hline & $\mathrm{N}$ & 26 & 26 & 26 & 26 & 26 \\
\hline \multirow[t]{3}{*}{$\overline{\mathrm{KPR}}$} & Pearson Correlation & .229 & .198 & 1 & $.664^{* *}$ & $.778^{* *}$ \\
\hline & Sig. (2-tailed) & .260 & .332 & & .000 & .000 \\
\hline & $\mathrm{N}$ & 26 & 26 & 26 & 26 & 26 \\
\hline \multirow[t]{3}{*}{$\overline{\mathrm{OB}}$} & Pearson Correlation & $.453^{*}$ & $.405^{*}$ & $.664^{* *}$ & 1 & $.767^{*}$ \\
\hline & Sig. (2-tailed) & .020 & .040 & .000 & & .000 \\
\hline & $\mathrm{N}$ & 26 & 26 & 26 & 26 & 26 \\
\hline \multirow[t]{3}{*}{$\overline{\mathrm{ZA}}$} & Pearson Correlation & .285 & .106 & $.778^{* *}$ & $.767^{* *}$ & 1 \\
\hline & Sig. (2-tailed) & .158 & .606 & .000 & .000 & \\
\hline & $\mathrm{N}$ & 26 & 26 & 26 & 26 & 26 \\
\hline
\end{tabular}

Through the analysis of data in Table 7, upon obtaining the factor correlation, it is concluded that the shown factor values are correlated, which enables the creation of certain suggestions influencing the improvement of the existing values. These suggestions can address the elimination of specific threats existing in a certain percentage within these protected areas. Also, suggestions can refer to the intensification of nature-based tourism, ecotourism development, the improvement of the existing infrastructure within the protected areas, etc. These can represent a significant part of the sectoral tourism development strategy (Ceausu, Gomes, \& Pereira, 2015; Doran, Hanss, \& Larsen, 2017).

The main research problem in this paper was that protected natural resources overlap territorially with many ethno villages. The tourism development strategy of the numerous villages has rural tourism development as the main plan. Nature protection and protected areas in common zones are complementary tourism motives. Visiting the protected area is the second tourism motive, realized after a visit to the ethno villages or other tourism events.

\section{CONCLUSION}

Indicators of sustainable tourism within five selected protected areas of the Autonomous Province of Vojvodina have been analyzed in the paper. These areas are specific spaces and attractive tourist destinations, in which many activities are limited since they can change the area and influence the natural resources and complete wildlife. The concept of 
such area protection provides the use of resources, but only in a sustainable and renewable way (Whittle, Stewart, \& Fisher, 2015; Font \& McCabe, 2017). It additionally increases the tourist value of these destinations. From the respondents' point of view, the indicators of sustainable tourism, with the highest average values marked are as follows: the significance of protection for species sustainability, the existence of hydrographic potential, the possibility of science tourism development, animals and bird watching, the existence of endangered wildlife, as well as indicators referring to the infrastructure within the area. Since the respondents gave answers with significant statistical differences, it is concluded that not all indicators are equally represented within these areas. It enables the constitution of certain proposals aimed at the improvement of these values. A conclusion that the assessed indicators within the selected protected areas are correlated can be used in support of that. Bearing in mind that the responses gave importance to tourism development, forms of tourism which can have a positive influence on these protected areas are as follows: nature-based tourism, ecotourism, bird watching, science tourism etc. The Constitution of a proposal for tourism development is the main objective of this paper. All specified forms of tourism will give priority to the protection of area and species. As the final result of the influence of area protection on the quality and type of destination, the environmental, economic and socio-cultural benefits for all participants of this unique system are distinguished. This is, at the same time, the main objective of sustainable tourism development.

\section{REFERENCES}

Bello, F.G., Carr, N. \& Lovelock, B. (2016). Community participation framework for protected area-based tourism planning. Tourism Planning \& Development, 13(4), 469-485. https://doi.org/10.1080/21568316.2015.1136838

Bennett, N.J., Whitty, T.S., Finkbeiner, E., Pittman, J., Bassett, H., Gelcich, S., \& Allison, E.H. (2018). Environmental stewardship: A conceptual review and analytical framework. Environmental Management, 61(4), 597-614. https://doi.org/10.1007/s00267-017-0993-2

Brandt, J., Christensen, A.A., Svenningsen, S.R., \& Holmes, E. (2013). Landscape practise and key concepts for landscape sustainability. Landscape Ecology, 28(6), 1125-1137. https://doi.org/10.1007/s10980-012-9777-5

Buclet, N., \& Lazarević, D. (2015). Principles for sustainability: the need to shift to a sustainable conventional regime. Environment, Development and Sustainability, 17(1), 83-100. https://doi.org/10.1007/s10668-014-9539-4

Butzmann, E., \& Job, H. (2017). Developing a typology of sustainable protected area tourism products. Journal of Sustainable Tourism, 25(12), 1736-1755. doi:10.1080/09669582.2016.1206110

Carr, A., Ruhanen, L., \& Whitford, M. (2016). Indigenous peoples and tourism: The challenges and opportunities for sustainable tourism. Journal of Sustainable Tourism, 24(8-9), 1067-1079. https://doi.org/10.1080/09669582.2016.1206112 
Ceauşu, S., Gomes, I., \& Pereira, H.M. (2015). Conservation planning for biodiversity and wilderness: a real-world example. Environmental Management, 55(5), 1168-1180. https://doi.org/10.1007/s00267-015-0453-9

Cvijanović, D., Stanišić, T., Leković, M., \& Kostić, M. (2020). Indicators of agricultural and rural development in the East Central and South-East European countries. Agriculture \& Forestry, 66(2), 19-32. https://doi.org/10.17707/AgricultForest. 66.2 .02

Doran, R., Hanss, D., \& Larsen, S. (2017). Intentions to make sustainable tourism choices: Do value orientations, time perspective, and efficacy beliefs explain individual differences? Scandinavian Journal of Hospitality and Tourism, 17(3), 223-238. https://doi.org/10.1080/15022250.2016.1179129

Eagles, P.F.J. (2014). Research priorities in park tourism. Journal of Sustainable Tourism, 22(4), 528-549. https://doi.org/10.1080/09669582.2013.785554

Eagles, P.F.J., McCool, S.F., \& Haynes, C.D. (2002). Sustainable tourism in protected areas, guidelines for planning and management. Cambridge: UNEP \& WTO.

Fennell, D.A. (2015). Ecotourism. London \& New York: Routledge.

Font, X., \& McCabe, S. (2017). Sustainability and marketing in tourism: Its contexts, paradoxes, approaches, challenges and potential. Journal of Sustainable Tourism, 25(7), 869-883. https://doi.org/10.1080/09669582.2017.1301721

Geneletti, D., Scolozzi, R., \& Esmail, B.A. (2018). Assessing ecosystem services and biodiversity tradeoffs across agricultural landscapes in a mountain region. International Journal of Biodiversity Science, Ecosystem Services \& Management, 14(1), 188-208. doi:10.1080/21513732.2018.1526214

Hall, C.M. (2010). Tourism and biodiversity: more significant than climate change? Journal of Heritage Tourism, 5(4), 253-266. https://doi.org/10.1080/1743873X. 2010.517843

Holden, A. (2016). Environment and tourism. London \& New York: Routledge.

Joshi, A., Kale, S., Chandel, S., \& Pal, D.K. (2015). Likert scale: explored and explained. British Journal of Applied Science \& Technology, 7(4), 396-403. https://doi.org/10.9734/BJAST/2015/14975

Lazić, L., Pavić, D., Stojanović, V., Tomić, P., Romelić, J., Pivac, T., Košić, K., Besermenji, S., \& Kicošev, S. (2008). Zaštićena prirodna dobra i ekoturizam Vojvodine [Protected natural resources and ecotourism in Vojvodina]. Novi Sad: Univerzitet u Novom Sadu, Prirodno-matematički fakultet, Departman za geografiju, turizam i hotelijerstvo.

Maksin, M., Ristić, V., Nenković-Riznić, M., \& Mićić, S. (2018). The role of zoning in the strategic planning of protected areas: Lessons learnt from EU countries and Serbia. European Planning Studies, 26(4), 838-872. https://doi.org/10.1080/ 09654313.2018.1426736

Milićević, S., Petrović, J., Kostić, M., \& Lakićević, M. (2020). Tourism product in the function of improving destination competitiveness: Case of Vrnjačka Banja, Serbia. Quality - Access to Success, 21(178), 133-138.

Newsome, D., Moore, S.A., \& Dowling, R.K. (2013). Natural area tourism ecology, impacts and management. Toronto: Channel View Publications.

Nikolić, S. (2006). Turizam u zaštićenim prirodnim dobrima Srbije [Tourism in protected natural sites of Serbia]. Beograd: Zavod za zaštitu prirode Srbije.

Panjković, B. (2016). Zaštićena područja prirode u AP Vojvodini, status zaštite $i$ finansiranje u kontekstu evropskih integracija [Protected Areas in Vojvodina, Status and Funding in the Context of European Integration]. Vršac: Ekološki centar „Stanište“.

Puzović, S., Panjković, B., Tucakov, M., Stojnić, N., Sabadoš, K., Stojanović, T., Vig, L., Marić, B., Tešić, O., Kiš, A., Galamboš, L., Pil, N., Kicošev, V., Stojšić, 
V., Timotić, D., Perić, R., Bošnjak, T., Delić, J., Dobretić, V., \& Stanišić, J. (2015). Upravljanje prirodnom baštinom u Vojvodini [Natural heritage management in Vojvodina]. Novi Sad: Pokrajinski sekretarijat za urbanizam, graditeljstvo i zaštitu životne sredine, Pokrajinski zavod za zaštitu prirode.

Saarinen, J., Rogerson, C.M., \& Hall, C.M. (2017). Geographies of tourism development and planning. Tourism Geographies, 19(3), 307-317. https://doi.org/10.1080/ 14616688.2017.1307442

Štetić, S., \& Trišić, I. (2018). The role and importance of ecosystems in creating tourism activities. Hotel and Tourism Management, 6(2), 35-46. https://doi.org/10.5937/ menhottur1802043S

Štetić, S., Trišić, I., \& Nedelcu, A. (2019). Natural potentials of significance for the sustainable tourism development - the focus on the special nature reserve. Journal of the Geographical Institute "Jovan Cvijič" SASA, 69(3), 279-287. https://doi.org/10.2298/IJGI1903279S

Stojanović, V. (2011). Turizam i održivi razvoj [Tourism and sustainable development]. Novi Sad: Univerzitet u Novom Sadu, Prirodno-matematički fakultet, Departman za geografiju, turizam i hotelijerstvo.

Stojanović, V., Lazić, L., \& Đunić, J. (2018). Nature protection and sustainable tourism interaction in selected Ramsar sites in Vojvodina (Northern Serbia). Geographica Pannonica, 22(3), 201-207. doi:10.5937/gp22-16637

Stojnić, N. Panjković, B., Sabadoš, K., Kicošev, V., Timotić, D., Kiš, A., Galamboš, L., Delić, J., Dobretić, V., Milenić, B., Perić, R., Stojšić, V., Pil, N., Stanišić, J., Plemić, Z., Predojević, J., Bošnjak, T., Mihajlović, N., Fojkar, O., Došenović, B., Marinković, L., Krnčević, G., Borčić, S., Novaković, S., Rilak, S., Dragaš, K., \& Pivaš, B. (2015). Izveštaj o stanju prirode u Autonomnoj Pokrajini Vojvodini za period 2010-2014 [Report on nature condition in Autonomous Province of Vojvodina for period 2010-2014]. Novi Sad: Republika Srbija, Autonomna Pokrajina Vojvodine, Pokrajinski zavod za zaštitu prirode.

Trišić, I. (2019). Opportunities for sustainable tourism development and nature conservation in Special Nature Reserve "Deliblatska Peščara". Hotel and Tourism Management, 7(1), 83-93. https://doi.org/10.5937/menhottur1901083T

Trišić I. (2020). Natural resources for the nature-based tourism development of the Vojvodina Province. Hotel and Tourism Management, 8(2), 101-112. https://doi.org/10.5937/menhottur2002101T

Trišić, I., Stetić, S., \& Krstić, V. (2018). Possibilities to prevent negative environmental impacts. Economics of Agriculture, 65(4), 1599-1614. https://doi.org/10.5937/ ekoPolj1804599T

Trišić, I., Štetić, S., Privitera, D., \& Nedelcu, A. (2020). Wine routes in Vojvodina Province, Northern Serbia - a tool for sustainable tourism development. Sustainability, 12(1), 82. https://doi.org/10.3390/su12010082

Wardle, C., Buckley, R., Shakeela, A., \& Castley, J.G. (2018). Ecotourism's contributions to conservation: Analysing patterns in published studies. Journal of Ecotourism. https://doi.org/10.1080/14724049.2018.1424173

Whittle, P.M., Stewart, E.J., \& Fisher, D. (2015). Re-creation tourism: de-extinction and its implications for nature-based recreation. Current Issues in Tourism, 18(10), 908-912. doi:10.1080/13683500.2015.1031727

Williams, S. \& Lew, A.A. (2015). Tourism geography, critical understandings of place space and experience. London \& New York: Routledge, Taylor \& Francis Group.

Zakon o zaštiti prirode [Law on Nature Protection] ("Službeni Glasnik RS“, br. 36/2009, 88/2010, 91/2010 - ispr. i 14/2016). 


\title{
ФУНКЦИЈА ЗАШТИЋЕНИХ ПРИРОДНИХ ПОДРУЧЈА ВОЈВОДИНЕ У ОДРЖИВОМ ТУРИСТИЧКОМ РАЗВОЈУ
}

\author{
Игор Тришић \\ Универзитет у Крагујевцу, Факултет за хотелијерство и туризам, \\ Врњачка Бања, Србија
}

\begin{abstract}
Резиме
Развој туризма у осетљивим дестинацијама, какви су заштићени природни простори, мора бити усклађен са природним, еколошким, социо-културним и економским принципима, по питању одрживог туристичког развоја. Уколико не постоји јасан концепт управљања и деловања на факторе одрживости, може доћи до негативних последица по све субјекте ових туристичких дестинација. Планирање је нарочито важно за заштићене просторе, како би се расположиви ресурси користили на одговарајући начин, а локална заједница била у потпуности укључена у системе заштите и управљања. На тај начин обезбеђује се адекватан доживљај туриста, што утиче на њихово задовољство и искуство у заштићеном простору. Имајући у виду повољан географски и туристички положај одабраних заштићених природних простора АП Војводине, у оквиру Србије и према државама у окружењу, то представља значајан потенцијал за туристичку тражњу за туристичким производом какав је туризам заснован на природи. Након спроведеног истраживања међу 250 домаћих и страних туриста, те анализе одговора који су се тицали нивоа и степена развоја туризма, као и значаја заштите простора, дошло се до значајних закључака. Према одговорима испитаника, заштићени природни простори АП Војводине могу представљати важну регионалну и међународну туристичку дестинацију одрживог туризма или других облика утемељених на природи. Разлог за то је што ови простори поседују значајне факторе одрживости, које су туристи препознали приликом посета Као највише оцењени јесу фактори локација, поседовање угрожених биљних и животињских врста, унапређење заштите, могућност развоја различитих облика туризма утемељених на природи, присуство влажних станишта и ретких екосистема и други. Наведени фактори чине ове просторе јединственом туристичком дестинацијом и могу бити предмет интересовања различитих група туриста. Након анализе добијених резултата истраживања, дошло се до закључка да заштићени природни простори АП Војводине могу представљати врло привлачне дестинације, у којима се могу остварити значајни социо-културни, еколошки и економски резултати одрживог туристичког развоја.
\end{abstract}

